\title{
ERRATA
}

\section{Close Association of Azospirillum and Diazotrophic Rods with Different Root Zones of Kallar Grass}

\author{
BARBARA REINHOLD, THOMAS HUREK, ERNST-GEORG NIEMANN, AND ISTVAN FENDRIK \\ Institute of Biophysics, University of Hannover, D-3000 Hanover, Federal Republic of Germany
}

Volume 52, no. 3, p. 522, Table 1, footnote $a$ : “(19)" should read “(29)."

Page 522, column 2, line 12: “(339” should read “(33).”

Page 523, Table 2, column 4, heading: "Increase in nitrogen content ${ }^{b}$ " should read "Increase in nitrogen content ( $\mu$ g of $\mathrm{N})^{b} . "$

Phenotypic Characteristics of Coliform and Noncoliform Bacteria from a Public Water Supply Compared with Regional and National Clinical Species STEPHEN C. EDBERG, VINCENT PISCITELLI, AND MATTHEW CARTTER

Department of Laboratory Medicine, Yale University School of Medicine, New Haven, Connecticut 06510, and Division of Field Services, Centers for Disease Control, Atlanta, Georgia 30333

Volume 52, no. 3, p. 476, Table 2, column 1 ( $\beta-G l u)$, row 16 of field: " 100 " should read “ $0 . "$

Column 2 (ONPG), row 16 of field: “"0” should read " 100 ." 